International Business and Global Economy 2019, no. 38, pp. 38-55

Biznes międzynarodowy w gospodarce globalnej 2019, nr 38, s. 38-55

Edited by the Institute of International Business, University of Gdańsk

ISSN 2300-6102

e-ISSN 2353-9496

DOI 10.4467/23539496IB.19.003.11502

\author{
Eugeniusz Gostomski \\ Uniwersytet Gdański \\ Tomasz Michałowski \\ Uniwersytet Gdański
}

\title{
Główne zmiany w światowym handlu usługami
}

Lata 1980-2017 to okres bardzo szybkiego wzrostu światowego handlu usługami. Ekspansji sektora usługowego w skali międzynarodowej towarzyszą zmiany zarówno struktury rzeczowej, jak i geograficznej światowej wymiany usług. Celem niniejszego opracowania jest przybliżenie zmian zachodzących w światowym handlu usługowym, wyjaśnienie ich przyczyn i wskazanie kierunków rozwoju międzynarodowego handlu usługowego w najbliższych latach. Autorzy oparli swoje rozważania na analizie opracowań specjalistów z zakresu poruszanej tematyki, jak i analizie danych statystycznych pozyskanych od różnych instytucji i organizacji międzynarodowych. Autorzy zauważają, że międzynarodowy handel usługami rośnie szybciej niż międzynarodowa wymiana towarowa, wzrasta przy tym znaczenie eksportu usług biznesowych oraz usług informacyjnych, informatycznych i telekomunikacyjnych kosztem znaczenia eksportu usług transportowych i usług związanych z dystrybucją towarów. W międzynarodowym handlu usługami zwiększa się udział krajów azjatyckich, zwłaszcza Chin i Indii.

Słowa kluczowe: usługi, handel, GATS, TiSA

Klasyfikacja JEL: F13, F14, P45

\section{Major changes in global trade in services}

In the period 1980-2017, we could see a rapid growth in global trade in services. The world-wide expansion of the service sector has been accompanied by changes in the structure of international trade in services. The aim of this study is to present the changes which have been taking place in global trade in services, to explain their determinants, and indicate the directions of development of international trade in services in the coming years. The study is based on the analysis of current research on trade in services, as well as on the analysis of statistical data obtained from various international institutions and organizations. The authors note that international trade in services is growing faster than international trade in goods. What is more, the importance of business services as well as information, IT, and telecommunications services exports is growing, while the importance of exports of transport services and services related to the distribution of goods is decreasing. The share of Asian countries, especially China and India, in international trade in services is increasing.

Keywords: services, trade, GATS, TiSA

JEL classification: E13, F14, P45 


\section{Wprowadzenie}

$W$ drugiej połowie $X X$ w. na świecie, szczególnie w krajach rozwiniętych, istotnie wzrosło znaczenie usług $\mathrm{w}$ życiu gospodarczym. Ich udział w tworzeniu produktu krajowego brutto i całkowitym zatrudnieniu w gospodarce narodowej w wielu krajach przekroczył $70 \%$. Przyczyniły się do tego m.in. następujące czynniki [Kłosiński, 2011, s. 40-41]:

- wzrost zamożności społeczeństwa i ilości czasu wolnego oraz wydłużanie się średniej długości życia stymulujące rozwój wielu rodzajów usług: gastronomicznych, turystycznych, edukacyjnych, kulturalnych, dotyczących ochrony zdrowia i innych,

- ekspansja sektora publicznego znajdująca wyraz w rozwoju usług doradczych na rzecz instytucji rządowych, usług $\mathrm{w}$ zakresie bezpieczeństwa publicznego, oświaty, ochrony zdrowia, transportu publicznego, opieki społecznej, ochrony środowiska, zaopatrzenia w wodę czy w misjach wojskowych itp.,

- wzrost produkcji towarów, który pociągnął za sobą rozwój usług towarzyszących obrotowi towarowemu: transportowych, spedycyjnych, ubezpieczeniowych, finansowych, doradztwa podatkowego i innych,

- postęp techniczny, dzięki któremu powstały nowe rodzaje usług, np. związane z Internetem i telefonią komórkową, a część tradycyjnych usług może być świadczona na odległość,

- rozwój globalizacji, który zwiększył zapotrzebowanie na podróże zagraniczne oraz wszelkie usługi związane z przepływem informacji i towarów w skali międzynarodowej.

Ekspansja sektora usługowego następuje nie tylko w poszczególnych krajach, ale także w skali międzynarodowej. Jak wynika z danych Konferencji Narodów Zjednoczonych ds. Handlu i Rozwoju, w latach 1980-2017 światowy handel usługami rozwijał się szybciej niż międzynarodowy handel towarami przetworzonymi i surowcami. Nominalnie wartość światowego eksportu usług w latach 1980-2017 wzrosła z około 396 mld USD do 5351 mld USD w 2017 r., a więc 13,5 razy, podczas gdy światowy eksport towarów zwiększył się w tym czasie z około 1981 mld USD do 17409 mld USD (8,8 razy). W okresie tym średnie roczne tempo wzrostu międzynarodowego obrotu usługowego wynosiło 7,3\%, a obrotu towarami 6,0\%. W efekcie udział wartości światowego handlu usługami w łącznej wartości światowych obrotów towarami i usługami zwiększył się z 16,7\% w 1980 r. do 23,5\% w 2017 r. ${ }^{1}$ Jednocześnie istotnie zmieniła się struktura geograficzna i przedmiotowa międzynarodowego handlu usługami.

\footnotetext{
1 Obliczenia własne na podstawie: [UNCTAD, 2018].
} 
Celem niniejszego opracowania jest przybliżenie zmian zachodzących w światowym handlu usługowym, wyjaśnienie ich przyczyn i wskazanie kierunków rozwoju międzynarodowego handlu usługowego w najbliższych latach.

\section{Specyfika usług i jej wpływ na międzynarodowy handel usługami}

Usługi są bardzo zróżnicowane i nieustannie pojawiają się ich nowe rodzaje, co utrudnia ich zdefiniowanie i sporządzenie ich kompletnej listy. Najczęściej określa się je jako wszelkie społecznie użyteczne czynności nie związane bezpośrednio z wytwarzaniem przedmiotów, wykonywane przez trudniące się tym zawodowo podmioty za zgodą zleceniodawcy i prowadzące do zmiany stanu ich konsumenta lub należącego doń przedmiotu materialnego [Kuźnar, 2007, s. 9-14]. Charakterystycznymi cechami znacznej części usług pozwalającymi na ich odróżnienie od produktów są:

- niematerialność - przy czym chodzi tutaj o samą użyteczność usługi, a nie o efekt działalności usługowej, który może być również materialny (np. w usługach gastronomicznych czy budowlanych); cecha ta sprawia, że transakcje usługowe trudno jest zmierzyć, monitorować i opodatkować,

- heterogeniczność - usługi są bardzo zróżnicowane i nie poddają się standaryzacji, co spowodowane jest uczestnictwem ludzi w procesie ich świadczenia,

- nierozdzielność - tradycyjnie oznaczało to, że świadczenie i konsumpcja usług musiały następować $\mathrm{w}$ tym samym miejscu, potrzebny był zatem bezpośredni kontakt między producentem i konsumentem usług, ale dzisiaj w dobie rozwoju technologii IT często nie jest to już konieczne,

- nietrwałość - dotycząca świadczenia usług, ale nie ich efektów.

Z usług korzystają zarówno indywidualni konsumenci, jak i przedsiębiorstwa i inne podmioty, tak w kraju, jak i za granicą. Można wyróżnić:

- usługi rynkowe, które świadczone są $w$ ramach działalności gospodarczej (transport, usługi finansowe, gastronomiczne, hotelarskie, naprawy itp.),

- usługi nierynkowe (niehandlowe), do których zalicza się głównie usługi sektora publicznego: edukacyjne, medyczne, opieki społecznej, transport miejski itp.

Jeżeli usługi są realizowane na podstawie transakcji zawartej między rezydentem jednego kraju (taki status mają też cudzoziemcy, którzy przebywają $\mathrm{w}$ danym państwie dłużej niż rok) a rezydentem innego kraju, mamy do czynienia z międzynarodową wymianą usług. Tak do międzynarodowych transakcji usługowych podchodzi Międzynarodowy Fundusz Walutowy (MFW), umiesz- 
czając płatności z tego tytułu na rachunku obrotów bieżących bilansu płatniczego [IMF, 2009, s. 70]. MFW dzieli usługi na następujące grupy:

- usługi transportowe,

- podróże zagraniczne (służbowe i prywatne),

- usługi budowlane,

- usługi ubezpieczeniowe,

- usługi finansowe,

- usługi komputerowe, informatyczne i informacyjne,

- udostępnianie prawa do korzystania z własności intelektualnej,

- pozostałe usługi biznesowe,

- usługi dla ludności (kulturalne, rozrywkowe),

- usługi rządowe.

Ze względu na sposób ewidencjonowania usług międzynarodowych w opracowaniach statystycznych rozróżnia się usługi samodzielne (transportowe, podróże zagraniczne, telekomunikacyjne, finansowe itp.) oraz usługi niesamodzielne, które związane są z przemieszczaniem się w skali międzynarodowej pracowników, kapitału i własności intelektualnej. Tych ostatnich nie ujmuje się odrębnie w statystykach dotyczących międzynarodowego handlu usługami, co jest jednym z powodów niedoszacowania jego rozmiarów ${ }^{2}$.

Układ ogólny w sprawie handlu usługami (General Agreement on Trade in Services - GATS) klasyfikuje usługi ze względu na cztery sposoby dotarcia z usługą do zagranicznego nabywcy (konsumenta), którymi są [WTO, 1994, Art. 1; Breinlich, 2018, s. 8-9]:

- handel transgraniczny - obejmuje wszystkie transakcje, w których producent usług i konsument pozostają w swoich krajach, jak ma to miejsce w przypadku zagranicznych usług bankowych, ubezpieczeniowych, części usług informatycznych czy obsługi klientów brytyjskich przez hinduskie call centres,

- konsumpcja usług za granicą - konsument określonej usługi zagranicznej udaje się do kraju jej producenta, jak ma to miejsce w przypadku turystyki zagranicznej, studiów i kursów zagranicznych, naprawy sprzętu w obcych krajach itp.,

- obecność handlowa za granicą - przedsiębiorstwa, np. banki, otwierają za granicą oddziały lub tworzą spółki zależne, aby sprzedawać tam swoje usługi, jednakże ich działalność z tego powodu, iż zatrudniają przede wszystkim rezydentów, w świetle definicji bilansu płatniczego nie może być zaliczana do międzynarodowego handlu usługowego,

2 Istnieją też inne powody niedoszacowania wielkości międzynarodowych obrotów usługowych część państw nie rejestruje obrotów niektórymi usługami, np. biznesowymi, inne kraje rejestrują tylko saldo obrotów usługowych, często usługi są tak ściśle związane z obrotem towarowym, że nie sposób oddzielnie oszacować ich wartość, nie zawsze rejestrowane są usługi realizowane w ramach korporacji międzynarodowych, niektóre usługi świadczone są w szarej strefie, a firmy ukrywające pewne dochody nie rejestrują wszystkich sprzedawanych usług, zob. [Kuźnar, 2007, s. 219-220]. 
- wyjazd za granicę oferentów usług - producent usługi udaje się na pewien czas za granicę i tam pracuje, obsługując miejscowych klientów, co dotyczy osób pracujących w różnych zawodach: budowlańców, mechaników samochodowych, kierowców, lekarzy, pielęgniarek, personelu pomocniczego i innych.

Pewne rodzaje usług z różnych powodów nie uczestniczą w handlu międzynarodowym, a pozostałe są przedmiotem handlu międzynarodowego $\mathrm{w}$ bardzo różnym stopniu. Niskim stopniem umiędzynarodowienia charakteryzują się regulowane przez państwo usługi użyteczności publicznej, takie jak transport kolejowy i lotniczy, dystrybucja wody i prądu oraz usługi świadczone głównie przez instytucje publiczne: usługi edukacyjne, medyczne, pomoc osobom najsłabszym. Natomiast stosunkowo silnie umiędzynarodowione są usługi transportowe, bankowe, turystyczne i informatyczne. Jak podaje Andżelika Kuźnar [2007, s. 216], w 1980 r. przedmiotem handlu międzynarodowego było około 5\% wszystkich wytwarzanych usług, a w 2000 r. 7\%, podczas gdy w przypadku towarów wskaźnik umiędzynarodowienia wynosił ponad $50 \%$.

Na szczególną uwagę zasługują nowe formy międzynarodowego handlu usługami związane z dynamicznym rozwojem na świecie w ostatnim ćwierćwieczu offshoringu usług, nazywanego też międzynarodowym outsourcingiem. Offshoring usług polega na wydzieleniu ze struktury macierzystego przedsiębiorstwa części usług biznesowych, IT i badawczo-rozwojowych, a następnie przekazaniu ich do wykonania przedsiębiorstwom $\mathrm{w}$ krajach o niższych kosztach pracy lub o większych zasobach kapitału intelektualnego, przy czym mogą to być tworzone do tego celu własne przedsiębiorstwa lub obce firmy [Ciesielska, 2009, s. 21]. Od outsourcingu różni się tym, że ma charakter międzynarodowy. Konsekwencją omawianego tutaj offshoringu jest rozwój importu usług. Wpływ na ekspansję offshoringu usług miały rozwój technologii telekomunikacyjno-informacyjnych, zaostrzanie się globalnej konkurencji oraz liberalizacja przepisów dotyczących międzynarodowego handlu usługami. W praktyce offshoring usług najczęściej występuje jako:

- outsourcing procesów biznesowych (ang. business process offshoring - BPO),

- centrum usług wspólnych (ang. shared services centres - SSC),

- offshoring usług $\mathrm{w}$ dziedzinie IT,

- offshoring procesów opartych na wiedzy (ang. knowledge process offshoring $\mathrm{KPO})$.

BPO obejmuje przenoszenie określonych funkcji przedsiębiorstwa, takich jak obsługa telefoniczna klientów, finanse i księgowość, wystawianie faktur dostawcom, wypłata wynagrodzeń pracownikom, usługi prawne, doradztwo, badanie rynku i innych, do zagranicznych centrów usługowych, które nie są powiązane kapitałowo z usługobiorcą.

Centrum usług wspólnych SSC wykonuje podobne usługi jak BPO, ale nie jest to firma obca, lecz wydzielony dział (ang. back office) lub utworzona za granicą 
firma należąca w pełni do usługobiorcy, dla którego na zasadzie wyłączności świadczy usługi. Zatem w przypadku utworzenia za granicą SSC mamy do czynienia $\mathrm{z}$ bezpośrednią inwestycją zagraniczną.

Offshoring w sferze IT związany jest $\mathrm{z}$ technologiami informatycznymi oraz określonymi procesami występującymi w łańcuchu wartości przedsiębiorstwa. Obejmuje on następujące procesy: wdrażanie lub obsługa nowoczesnych technologii informatycznych, czynności związane z wykorzystaniem Internetu i e-commerce, kontrola bezpieczeństwa i przetwarzanie danych oraz inne nowoczesne usługi.

Przedmiotem KPO są skomplikowane usługi oparte na kapitale ludzkim i wiedzy: inżynierskie, projektowe, prawne, finansowe, usługi w zakresie badania rynku i inne. Wymagają one specjalistycznych umiejętności, wiedzy i doświadczenia ze strony zatrudnionych pracowników [Oczkowska, 2012].

\section{Dynamika i czynniki rozwoju międzynarodowego handlu usługami w latach 1980-2017}

Analizując dynamikę rozwoju światowego handlu usługami i porównując ją do tempa wzrostu wymiany towarów (produktów) na świecie, trzeba mieć na uwadze, że publikowane przez organizacje międzynarodowe (MFW, WTO, UNCTAD) dane statystyczne z zakresu międzynarodowego handlu usługami pochodzą z bilansów płatniczych poszczególnych krajów. Są one znacznie zaniżone w stosunku do jego rzeczywistej wartości, nie uwzględniają bowiem międzynarodowych obrotów usługami realizowanych w wyniku obecności przedsiębiorstw za granicą, czyli określonego wyżej trzeciego sposobu międzynarodowego handlu usługami, który to handel nie wchodzi do bilansu płatniczego. Gromadzenie danych statystycznych dotyczących tych obrotów jest możliwe tylko poprzez pozyskiwanie ich od zagranicznych oddziałów i spółek zależnych koncernów świadczących usługi na rzecz przedsiębiorstw macierzystych lub innych usługobiorców. Dane te najczęściej dostępne są tylko w ograniczonym stopniu i tylko dla krajów OECD. Jednakże na tej podstawie można stwierdzić, że usługi świadczone we wspomniany trzeci sposób w handlu międzynarodowym odgrywają większą rolę niż usługi świadczone w pierwszy, drugi i czwarty sposób. Jak podaje Lindsay Oldenski [2012, s. 312-322], wartość usług świadczonych przez amerykańskie koncerny za granicą (sposób trzeci) jest dwa razy większa niż suma wartości usług realizowanych w obrocie międzynarodowych trzema pozostałymi sposobami.

Jak wynika z danych umieszczonych w tabeli 1, w latach 1980-2000 światowy eksport usług nominalnie wzrósł 3,8 razy, a eksport towarów 3,2 razy, rozwijał się więc szybciej niż globalny eksport towarów. 


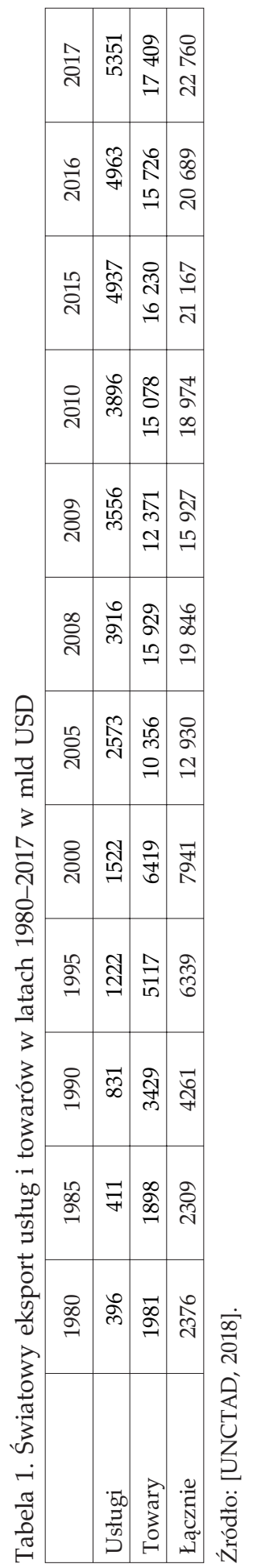


W 2000 r. wartość światowego eksportu usług stanowiła 19,2\% łącznej wartości międzynarodowej wymiany towarów i usług (wobec 16,7\% w 1980 roku). W latach 2000-2017 tempo wzrostu globalnego eksportu usług znacznie wyprzedzało dynamikę światowego eksportu towarowego. W efekcie zwiększył się ich udział w światowym eksporcie obejmującym łącznie towary i usługi z 19,2\% do 23,5\%.

Obroty usługami są mniej podatne na kryzysy w gospodarce światowej niż obroty towarowe - podczas gdy w kryzysowym 2009 r. światowy eksport towarów zmniejszył się o $22 \%$ w stosunku do roku poprzedniego, eksport usług obniżył się o $9 \%$.

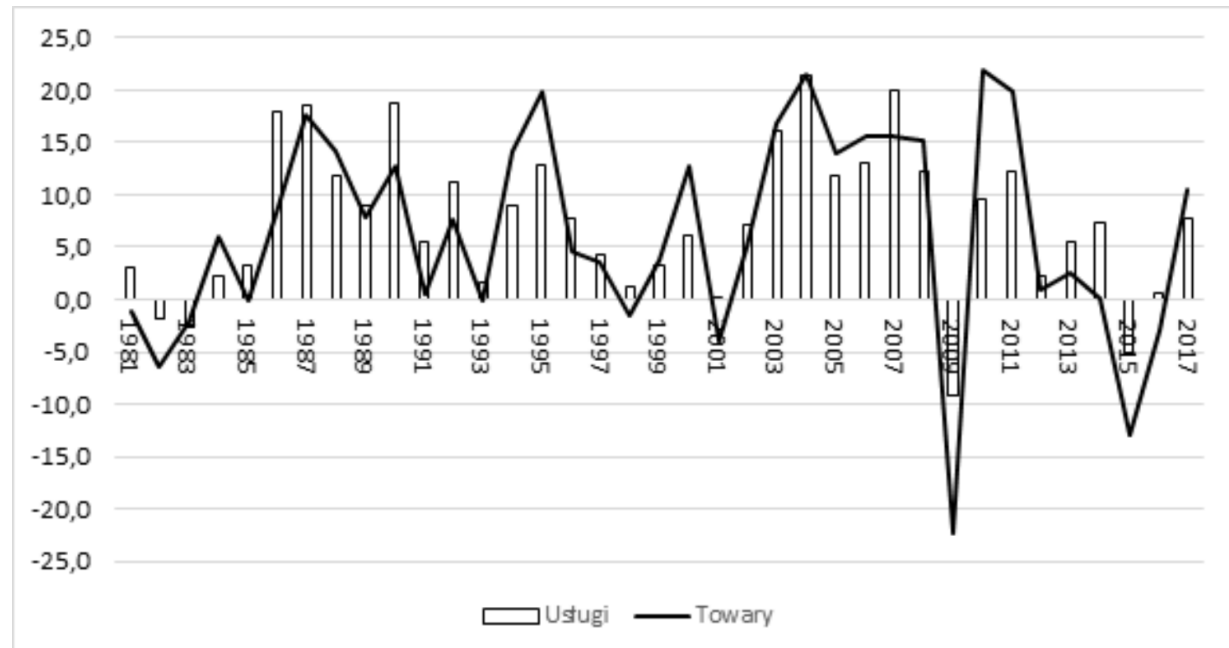

Rysunek 1. Zmiany wartości światowego eksportu towarów i usług w latach 1981-2017, roczne zmiany w \%

Źródło: Opracowanie własne na podstawie: [UNCTAD, 2018].

\section{Zmiany branżowej i geograficznej struktury międzynarodowej wymiany usług}

Stopniowo zmienia się zarówno rzeczowa, jak i geograficzna struktura światowego handlu usługami. W 2000 r. ponad połowa globalnego eksportu usług uwzględnionego w statystykach bilansu płatniczego przypadała na eksport usług transportowych wraz z dystrybucją towarów oraz podróże i turystykę zagraniczną. W 2015 r. udział usług transportowych i usług związanych z dystrybucją towarów w międzynarodowym eksporcie usługowym zmniejszył się o 7 pkt. proc. do poziomu $18 \%$, a udział podróży i turystyki zagranicznej o 5 pkt. proc. do $25 \%$. 
Towarzyszył temu duży wzrost eksportu usług biznesowych i pozostałych - o 5 pkt. proc. do poziomu $33 \%$. Usługi te obejmują m.in. usługi konsultingowe dla przedsiębiorstw, usługi prawne i marketingowe. W latach 2000-2015 odnotowano też duży wzrost znaczenia międzynarodowego handlu usługami informacyjnymi, informatycznymi i telekomunikacyjnymi. Natomiast udział eksportu usług finansowych i ubezpieczeniowych w całkowitym eksporcie usług zwiększył się o 1 pkt. proc. do poziomu $11 \%$. Mniejszą rolę w transgranicznym handlu usługami odgrywają usługi budowlane.

Tabela 2. Struktura globalnego eksportu usług w 2000 i 2015 r., w \%

\begin{tabular}{|l|r|l|r|}
\hline \multicolumn{2}{|c|}{$2000 \mathrm{r}}$. & \multicolumn{2}{c|}{$2015 \mathrm{r}}$. \\
\hline usługi biznesowe i pozostałe & 28 & usługi biznesowe i pozostałe & 33 \\
\hline usługi budowlane & 2 & usługi budowlane & 2 \\
\hline usługi finansowe & 10 & usługi finansowe & 11 \\
\hline usługi ICT & 6 & usługi ICT & 10 \\
\hline turystyka i podróże zagraniczne & 30 & turystyka i podróże zagraniczne & 25 \\
\hline transport i dystrybucja & 25 & transport i dystrybucja & 18 \\
\hline
\end{tabular}

Źródło: [HSBC Bank, 2016, s. 5].

Globalny eksport usług cechuje się wysoką koncentracją obrotów, ponieważ ponad połowa tego eksportu realizowana jest przez dziesięciu największych eksporterów. Dotychczas niekwestionowanym liderem były Stany Zjednoczone, których udział w globalnym eksporcie usług w latach 1980-2000 zwiększył się z 12\% do 19\%, a następnie obniżył się do 14,6\% w 2017 r. Swoją silną pozycję w największym stopniu zawdzięczają eksportowi następujących rodzajów usług: turystycznych, podróży zagranicznych, usług biznesowych i sprzedaży za granicę własności intelektualnej. Na drugim miejscu w globalnym eksporcie usług od 2000 r. plasuje się Wielka Brytania z udziałem 6,6\% (2017 r.). Brytyjski eksport usług jest bardzo zróżnicowany (usługi podróżnicze, edukacyjne, doradcze, informatyczne, marketingowe, architektoniczne i inne) i cieszy się wysoką renomą na świecie. Dużymi eksporterami usług są też Francja, Niemcy, Holandia, Włochy i Hiszpania. Swego rodzaju fenomen $w$ transgranicznych obrotach usługami stanowi licząca niecałe 5 mln mieszkańców Irlandia, która w 2017 r. zajmowała siódme miejsce w globalnym eksporcie i imporcie usług. Tak wysoką pozycję zawdzięcza ona przede wszystkim przenoszeniu przez korporacje wielonarodowe do Irlandii ze względu na niskie podatki i dostęp do wykwalifikowanych pracowników usług z branży ICT i usług kreatywnych. Od wielu lat w światowym handlu usługami zwiększa się znaczenie Chin, które zajmują już drugie miejsce w globalnym imporcie usług i piąte miejsce w ich eksporcie. Umacnia się też pozycja Indii, których atutem są nie tylko niskie koszty pracy, ale także posługiwanie się języ- 
kiem angielskim i dysponowanie stosunkowo dobrze wykształconą kadrą, co ułatwia kontakty biznesowe z firmami z angielskiego obszaru językowego i stymuluje rozwój usług offshoringowych (BPO, SSC, KPO). W ślady Indii próbuje pójść Bangladesz. Znaczącymi eksporterami usług, szczególnie turystycznych i transportowych, stały się też Egipt, Turcja i Zjednoczone Emiraty Arabskie.

Tabela 3. Głowni eksporterzy usług w latach 1980-2017, \% wartości światowego eksportu usług

\begin{tabular}{|c|l|c|l|c|c|c|c|c|c|c|}
\hline \multirow{2}{*}{ Lp. } & \multicolumn{2}{|c|}{$1980 \mathrm{r}}$. & \multicolumn{2}{c|}{$1990 \mathrm{r}}$. & \multicolumn{2}{c|}{$2000 \mathrm{r}}$. & \multicolumn{2}{c|}{$2010 \mathrm{r}}$. & \multicolumn{2}{c|}{$2017 \mathrm{r.}$} \\
\cline { 2 - 12 } & kraj & udział & kraj & udział & kraj & udział & kraj & udział & kraj & udział \\
\hline 1 & USA & 12,0 & USA & 17,8 & USA & 19,0 & USA & 14,3 & USA & 14,6 \\
\hline 2 & Francja & 11,0 & Francja & 8,2 & $\begin{array}{l}\text { Wielka } \\
\text { Brytania }\end{array}$ & 7,9 & $\begin{array}{l}\text { Wielka } \\
\text { Brytania }\end{array}$ & 6,9 & $\begin{array}{l}\text { Wielka } \\
\text { Brytania }\end{array}$ & 6,6 \\
\hline 3 & $\begin{array}{l}\text { Wielka } \\
\text { Brytania }\end{array}$ & 9,2 & Niemcy & 7,5 & Niemcy & 5,5 & Niemcy & 6,4 & Niemcy & 5,7 \\
\hline 4 & Niemcy & 8,3 & $\begin{array}{l}\text { Wielka } \\
\text { Brytania }\end{array}$ & 6,8 & Francja & 5,3 & Francja & 5,0 & Francja & 4,7 \\
\hline 5 & Japonia & 5,1 & Włochy & 6,0 & Japonia & 4,5 & Chiny & 4,2 & Chiny & 4,3 \\
\hline 6 & Włochy & 4,9 & Japonia & 5,0 & Włochy & 3,7 & Japonia & 3,6 & Holandia & 4,1 \\
\hline 7 & Holandia & 4,3 & Holandia & 3,5 & Hiszpania & 3,5 & Hiszpania & 3,2 & Irlandia & 3,5 \\
\hline 8 & Belgia & 3,3 & Belgia & 3,4 & Holandia & 3,4 & Holandia & 3,0 & Japonia & 3,5 \\
\hline 9 & Hiszpania & 2,9 & Hiszpania & 3,4 & Belgia & 3,3 & Indie & 3,0 & Indie & 3,4 \\
\hline 10 & Austria & 2,4 & Austria & 2,8 & $\begin{array}{l}\text { Hong- } \\
\text { kong }\end{array}$ & 2,7 & $\begin{array}{l}\text { Hong- } \\
\text { kong }\end{array}$ & 2,7 & Singapur & 3,1 \\
\hline
\end{tabular}

Źródło: Opracowanie własne na podstawie: [UNCTAD, 2018].

Jeżeli chodzi o obroty usługami w ujęciu bilateralnym, w latach 2000-2015 największe wzrosty odnotowano $\mathrm{w}$ przepływach pomiędzy gospodarkami rozwiniętymi. Wyjątek stanowią bardzo dynamicznie rosnące przepływy turystyczne z Hongkongu do Chin.

W ostatnich kilku latach w Polsce powstał bardzo silny sektor usług biznesowych ukierunkowanych głównie na eksport. Na początku 2018 r. funkcjonowało u nas 1236 centrów usług typu BPO, SSC, IT i R\&D - 396 polskich i 840 zagranicznych, w tym 83 należące do przedsiębiorstw z listy Fortune Global 500 z 2017 r. Zatrudniały one 279 tys. osób [ABSL, 2018]. W 2015 r. polski eksport usług osiągnął wartość 44 mld USD, a w 2030 r. może być na poziomie 124 mld USD [HSBC Bank, 2016, s. 15]. 


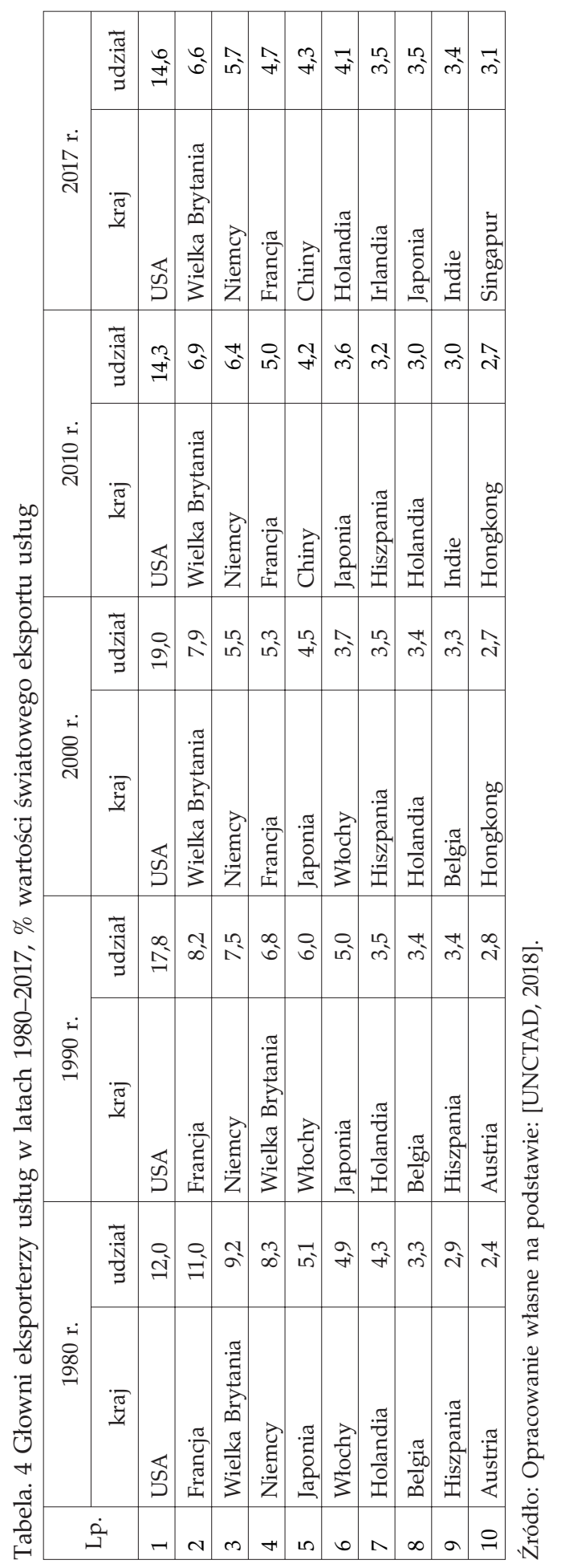




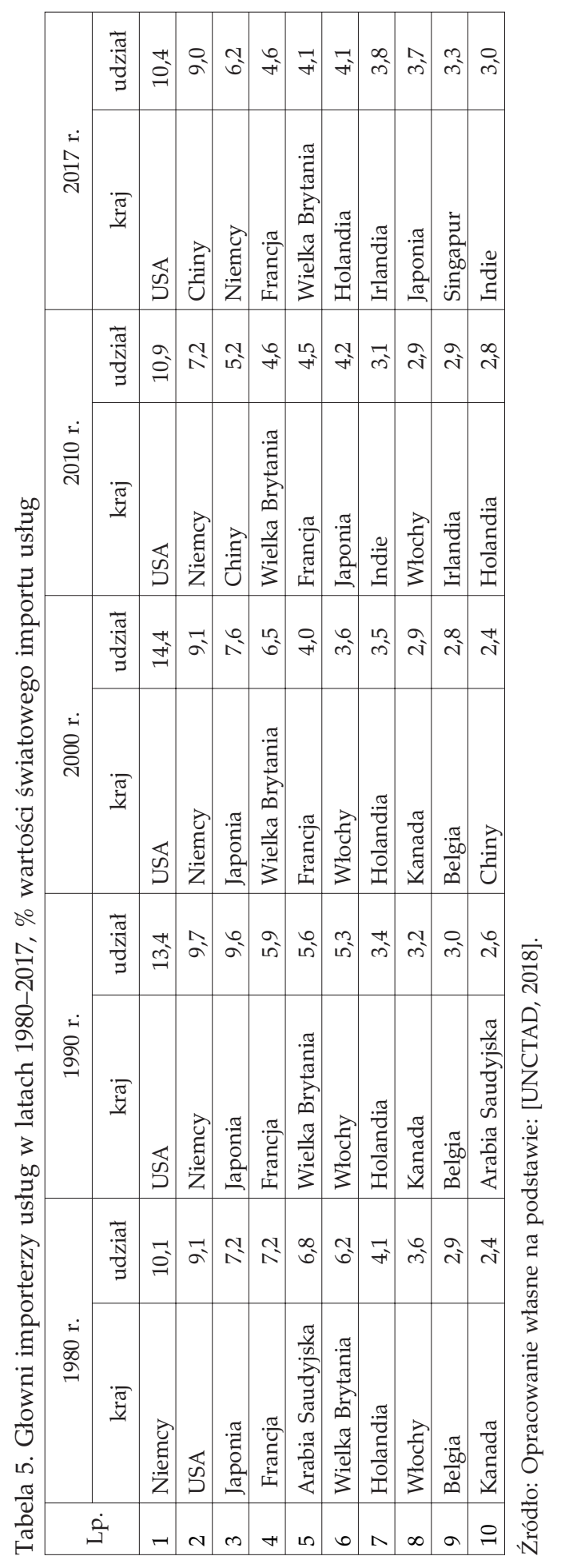


Tabela 6. Eksport usług - przepływy o największym wzroście w latach 2000-2015

\begin{tabular}{|r|l|l|l|}
\hline \multicolumn{1}{|c|}{ Lp. } & \multicolumn{1}{|c|}{ Kraj pochodzenia } & \multicolumn{1}{c|}{ Kraj przeznaczenia } & \multicolumn{1}{c|}{ Sektor } \\
\hline 1 & USA & Irlandia & usługi biznesowe i pozostałe \\
\hline 2 & Wielka Brytania & USA & usługi biznesowe i pozostałe \\
\hline 3 & Hongkong & Chiny & turystyka \\
\hline 4 & USA & Chiny & turystyka \\
\hline 5 & Japonia & USA & usługi biznesowe i pozostałe \\
\hline 6 & Niemcy & USA & usługi biznesowe i pozostałe \\
\hline 7 & Wielka Brytania & USA & usługi finansowe \\
\hline 8 & USA & Wielka Brytania & usługi finansowe \\
\hline 9 & Kanada & USA & usługi biznesowe i pozostałe \\
\hline 10 & USA & Kanada & turystyka \\
\hline
\end{tabular}

Źródło: [HSBC Bank, 2016, s. 7].

\section{Bariery w międzynarodowym obrocie usługami i próby wypracowania sektorowego Porozumienia w sprawie handlu usługami (TiSA)}

Dotychczas najważniejszym porozumieniem dotyczącym światowego handlu sługami jest wypracowany w ramach Rundy Urugwajskiej Układ ogólny w sprawie ceł i handlu (General Agreement on Tariffs and Trade - GATT) i obowiązujący od 1995 r. GATS [WTO, 1994].

Mimo wejścia w życie GATS poziom liberalizacji międzynarodowego obrotu usługowego jest ciągle stosunkowo niski. Wprawdzie transgraniczne usługi w przeciwieństwie do towarów nie są obciążane cłami, ale liczne bariery pozataryfowe utrudniają oferentom usług dostęp do rynków zagranicznych. Wymienić tutaj można takie działania rządów, jak ograniczanie udziałów zagranicznych w funkcjonujących w danym kraju przedsiębiorstwach usługowych, stosowanie rygorystycznej polityki wizowej wobec osób z zagranicy i stawianie im przy ubieganiu się o pozwolenie na świadczenie usług wyższych wymagań niż własnym obywatelom czy utrudnianie cudzoziemcom dostępu do infrastruktury informatycznej. Z reguły w krajach słabiej rozwiniętych bariery handlowe w dostępie do rynku usług są większe niż w krajach rozwiniętych.

Dalsza liberalizacja handlu usługami na świecie była przedmiotem rokowań prowadzonych na forum Światowej Organizacji Handlu (World Trade Organization - WTO) w ramach rozpoczętej w 2001 r. Rundy Doha. Podczas negocjacji ujawniły się niemożliwe do przezwyciężenia różnice w stanowiskach krajów rozwiniętych opowiadających się za większym otwarciem dla podmiotów zagranicznych krajowych rynków usług i krajów rozwijających się (krajami Południa), które oba- 
wiają się zdominowania ich rynków usługowych przez wielkie korporacje z państw wysoko rozwiniętych. Kraje Południa podkreślają też, że państwa wysoko rozwinięte nie oferują im w zamian za przyjęcie zobowiązań liberalizacyjnych wystarczających rekompensat w dostępie do ich rynków, a ponadto uzależniają liberalizację usług od liberalizacji handlu towarami rolno-spożywczymi [Wróbel, 2009, s. 203-204].

Wobec impasu w negocjacjach Rundy Doha Unia Europejska i 22 kraje pozaunijne3, które były zainteresowane szybką liberalizacją międzynarodowego ryn$\mathrm{ku}$ usług, podjęły plurilateralne rozmowy w sprawie zawarcia Porozumienia w sprawie handlu usługami (Trade in Services Agreement - TiSA). Łącznie realizują one około $70 \%$ światowego handlu usługami. Nowe porozumienie byłoby otwarte także dla innych państw i stanowiłoby uzupełnienie układu GATS. Do listopada 2016 r. w Genewie odbyło się 21 rund negocjacyjnych, po czym i te rozmowy utkwiły w martwym punkcie [EC, 2016].

\section{Perspektywy rozwoju handlu usługami do 2030 r.}

W najbliższych latach najważniejszymi motorami rozwoju międzynarodowego handlu usługami będą następujące czynniki:

- wzrost międzynarodowej wymiany towarów związany z globalizacją procesów gospodarczych i postępami w zakresie regionalnej integracji gospodarczej, co pociąga za sobą także zwiększenie eksportu i import usług: marketingowych, transportowych, finansowych, ubezpieczeniowych i innych,

- rozwój nowoczesnych technologii informatycznych i telekomunikacyjnych, który sprawia, że więcej rodzajów usług może być przedmiotem wymiany międzynarodowej,

- rozwój offshoringu usług umożliwiającego obniżenie kosztów usług wspierających kluczową działalność przedsiębiorstw w krajach rozwiniętych,

- zwiększanie się liczebności klasy średniej w gospodarkach wschodzących, szczególnie w krajach azjatyckich, co prowadzi do zwiększenia popytu na wiele rodzajów usług zagranicznych.

Natomiast negatywny wpływ na międzynarodowy handel usługami będą miały protekcjonistyczna polityka handlowa USA i wystąpienie Wielkiej Brytanii z Unii Europejskiej. Jeżeli trafna okaże się analiza statystyczna skutków Brexitu dokonana przez Monique Ebell [2016, s. R31-R32], brytyjski handel usługami z pozostałymi krajami UE, który w 2015 r. wyniósł 157 mld GBP (eksport 89 mld GBP,

3 Są to następujące kraje: Australia, Kanada, Chile, Tajwan, Kolumbia, Kostaryka, Hongkong-Chiny, Islandia, Izrael, Japonia, Korea, Liechtenstein, Meksyk, Mauritius, Nowa Zelandia, Norwegia, Pakistan, Panama, Peru, Szwajcaria, Turcja, Stany Zjednoczone. 
import 68 mld GBP), może obniżyć się nawet o 100 mld GBP, czyli ponad 60\%. Najbardziej ucierpiałyby następujące brytyjskie branże: sektor finansowy, transport lotniczy, usługi informatyczne i audiowizualne. Spadek obrotów usługowych nastąpiłby także w wyniku ograniczenia mobilności pracowników brytyjskich w UE i unijnych w Wielkiej Brytanii, zaostrzenia warunków uznawania zagranicznych kwalifikacji zawodowych oraz ograniczenia dla obu stron swobody zakładania przedsiębiorstw za granicą. Jednakże oczekuje się, że kraje UE będą mogły przynajmniej częściowo skompensować sobie negatywne skutki Brexitu wzrostem wymiany handlowej z Kanadą i Koreą Południową w wyniku utworzenia z tymi krajami strefy wolnego handlu.

Według prognozy HSBC i Oxford Economics wartość globalnego eksportu usług międzynarodowych wzrośnie z 4,9 bln USD w 2015 r. do 12,4 bln USD w 2030 r. Najszybciej będzie wzrastał eksport usług Indonezji, Bangladeszu, Indii, Malezji, Zjednoczonych Emiratów Arabskich (ZEA) i Egiptu. W wyniku szybszego rozwoju eksportu usług niż eksportu towarów udział globalnego eksportu usług w globalnym eksporcie towarów i usług w tym okresie zwiększy się z 23\% do $25 \%$ [HSBC Bank, 2016].

HSBC i Oxford Economics prognozują, że w latach 2015-2030 najszybciej będzie rósł eksport usług dla biznesu i pozostałych usług. Ich udział w globalnym eksporcie towarów i usług wzrośnie o 4 pkt. proc. do $37 \%$. U podstaw tej tendencji leży przede wszystkim dynamiczny rozwój nowoczesnych form offshoringu (BPO, SSC, KPO), z którego coraz częściej korzystają duże przedsiębiorstwa z krajów rozwiniętych. Zwiększać się będzie także udział usług ICT. Z powodu zaostrzenia regulacji rynków finansowych w krótkim okresie należy spodziewać się pewnego ograniczenia eksportu usług finansowych. Jednakże w dłuższej perspektywie ich znaczenie się zwiększy, głównie dzięki bogatym konsumentom z Azji, którzy będą zgłaszać zapotrzebowanie na nowoczesne usługi finansowe, także na oferowane przez podmioty zagraniczne. Wolniej będzie zwiększać się eksport takich usług, jak turystyka i podróże zagraniczne oraz transport i dystrybucja towarów.

Tabela 7. Prognozowana struktura globalnego eksportu usług, udział w \%

\begin{tabular}{|l|r|l|r|}
\hline \multicolumn{2}{|c|}{$2015 \mathrm{r}}$. & \multicolumn{2}{c|}{$2030 \mathrm{r}}$. \\
\hline usługi biznesowe i pozostałe & 33 & usługi biznesowe i pozostałe & 37 \\
\hline usługi budowlane & 2 & usługi budowlane & 2 \\
\hline usługi finansowe & 11 & usługi finansowe & 10 \\
\hline usługi ICT & 10 & usługi ICT & 11 \\
\hline turystyka i podróże zagraniczne & 25 & turystyka i podróże zagraniczne & 24 \\
\hline transport i dystrybucja & 18 & transport i dystrybucja & 16 \\
\hline
\end{tabular}

Źródło: [HSBC Bank, 2016, s. 10]. 
Według omawianej tutaj prognozy w 2030 r. pięcioma największymi eksporterami usług na świecie będą te same kraje co w 2015 r., ale udział USA, Wielkiej Brytanii, Niemiec i Francji w globalnym eksporcie usług się zmniejszy, a Chin wzrośnie. Zwiększy się też udział Indii i Japonii. Na liście dziesięciu największych eksporterów znajdą się ZEA. Większe zmiany nastąpią na liście czołowych importerów usług - zwiększy się znaczenie Chin, Indii i Korei Południowej, a zmniejszy krajów rozwiniętych: USA, Niemiec, Francji, Japonii i Irlandii.

Tabela 8. Najwięksi eksporterzy i importerzy usług w 2015 r. i 2030 r., udziały w globalnym eksporcie i imporcie usług w \%

\begin{tabular}{|r|r|r|l|r|l|r|l|c|}
\hline \multirow{2}{*}{ Lp. } & \multicolumn{5}{|c|}{ Eksport } & \multicolumn{5}{c|}{ Import } \\
\cline { 2 - 10 } & \multicolumn{2}{|c|}{$2015 \mathrm{r}}$. & \multicolumn{2}{c|}{$2030 \mathrm{r}}$. & \multicolumn{2}{c|}{$2015 \mathrm{r}}$. & \multicolumn{2}{c|}{$2030 \mathrm{r}}$. \\
\hline 1 & USA & 15,6 & USA & 13,2 & USA & 10,1 & Chiny & 13,4 \\
\hline 2 & W. Brytania & 7,1 & W. Brytania & 7,2 & Chiny & 9,7 & USA & 7,7 \\
\hline 3 & Chiny & 5,9 & Chiny & 6,6 & Niemcy & 6,2 & Niemcy & 5,8 \\
\hline 4 & Niemcy & 5,3 & Niemcy & 4,8 & Francja & 4,8 & Indie & 5,1 \\
\hline 5 & Francja & 5,0 & Francja & 4,6 & W. Brytania & 4,4 & W. Brytania & 4,6 \\
\hline 6 & Japonia & 3,4 & Indie & 4,2 & Japonia & 3,7 & Francja & 4,4 \\
\hline 7 & Indie & 3,2 & Japonia & 3,5 & Irlandia & 3,5 & Japonia & 3,4 \\
\hline 8 & Singapur & 2,9 & Singapur & 2,9 & Singapur & 3,0 & Korea Płd. & 3,0 \\
\hline 9 & Irlandia & 2,8 & Irlandia & 2,7 & Indie & 2,9 & Singapur & 3,0 \\
\hline 10 & Hongkong & 2,2 & ZEA & 2,7 & Korea Płd. & 2,4 & Irlandia & 2,7 \\
\hline
\end{tabular}

Źródło: [HSBC Bank, 2016, s. 7-8, 11-12].

\section{Podsumowanie}

Międzynarodowy handel usługami rośnie szybciej niż międzynarodowa wymiana towarowa. W latach 2000-2017 udział eksportu usług w łącznej wartości światowego eksportu towarów i usług wzrósł z 19,2\% do 23,5\%. Zaobserwować można przy tym zmiany w branżowej i geograficznej strukturze międzynarodowej wymiany usług. W latach 2000-2015 w międzynarodowym eksporcie usługowym zmniejszał się udział usług transportowych i usług związanych z dystrybucją towarów, rosło natomiast znaczenie eksportu usług biznesowych i pozostałych, obejmujących m.in. usługi konsultingowe dla przedsiębiorstw, usługi prawne i marketingowe. W analizowanym okresie odnotowano również znaczący wzrost znaczenia międzynarodowego handlu usługami informacyjnymi, informatycznymi i telekomunikacyjnymi. Globalny eksport usług cechuje się wysoką koncentracją obrotów. Od wielu lat w światowym handlu usługami zwiększa się znaczenie Chin oraz umacnia pozycja Indii. 
W najbliższych kilkunastu latach międzynarodowy handel usługami nadal będzie się dynamicznie rozwijał. Do najważniejszych czynników jego rozwoju należy zaliczyć ekspansję sektora usługowego w krajach rozwiniętych i gospodarkach wschodzących, rozwój nowoczesnych technologii informatycznych i telekomunikacyjnych umożliwiających eksport i import coraz szerszej palety usług oraz postępujące procesy integracyjne w gospodarce światowej. Negatywnie na ekspansję transgranicznych obrotów usługami wpłynie zapewne Brexit ze względu na dużą rolę Wielkiej Brytanii w globalnym eksporcie i imporcie usług. Najszybciej będzie rósł globalny eksport i import usług informacyjnych, informatycznych i telekomunikacyjnych. USA utrzymają się na pozycji największego na świecie eksportera usług, ale już w imporcie usług liderem za kilka lat będą Chiny. W międzynarodowym handlu usługami zwiększy się też znaczenie innych krajów azjatyckich kosztem krajów europejskich.

Bibliografia

ABSL, 2018, Sektor nowoczesnych ustug biznesowych w Polsce 2018, ABSL, Warszawa, https://absl.pl/wp-content/uploads/2018/06/raport_absl_2018_PL_180527_epub-1.pdf [dostęp: 15.11.2019].

Breinlich H., 2018, Historische und aktuelle Perspektiven im Dienstleistungshandel, Wirtschaftsdienst, Sonderheft.

Ciesielska D., 2009, Offshoring ustug. Wptyw na rozwój przedsiębiorstwa, Wolters Kluwer Polska, Warszawa.

Ebell M., 2016, Assessing the impact of trade agreements on trade, National Institute Economic Review, no. 238.

EC, 2016, Abkommen über den Handel mit Dienstleistungen (TiSA), European Commission, http://trade.ec.europa.eu/doclib/docs/2016/november/tradoc_155106.pdf [dostęp: 03.11.2018].

HSBC Bank, 2016, Unlocking the growth potential of services trade, HSBC Commercial Banking, London.

IMF, 2009, Balance of payments and international investment position manual, International Monetary Fund, Washington, DC, https://www.imf.org/external/pubs/ft/bop/2007/pdf/ bpm6.pdf [dostęp: 15.11.2019].

Kłosiński K., 2011, Światowy rynek ustug w początkach XXI wieku, PWE, Warszawa.

Kuźnar A., 2007, Ustugi w handlu międzynarodowym, Wydawnictwo Adam Marszałek, Toruń.

Oczkowska R., 2012, Offshoring jako szansa wykorzystania globalnych zasobów kapitału ludzkiego, Nierówności Społeczne a Wzrost Gospodarczy, nr 26.

Oldenski L., 2012, Export versus FDI and the communication of complex information, Journal of International Economics, no. 2.

UNCTAD, 2018, UNCTADstat, http://unctadstat.unctad.org [dostęp: 05.11.2018].

Wróbel A., 2009, Międzynarodowa wymiana ustug, Scholar, Warszawa. 
WTO, 1994, General Agreement on Trade in Services, https://www.wto.org/english/ docs_e/legal_e/26-gats_01_e.htm [dostęp: 03.11.2018].

E. Gostomski (®) egostomski@wp.pl

Instytut Handlu Zagranicznego, Wydział Ekonomiczny, Uniwersytet Gdański, ul. Armii Krajowej 119/121, 81-824 Sopot, Polska

T. Michałowski (-) t.michalowski@ug.edu.pl Instytut Handlu Zagranicznego, Wydział Ekonomiczny, Uniwersytet Gdański, ul. Armii Krajowej 119/121, 81-824 Sopot, Polska 